\title{
The Additional Costs per Month of Progression-Free Survival and Overall Survival: An Economic Model Comparing Everolimus with Cabozantinib, Nivolumab, and Axitinib for Second-Line Treatment of Metastatic Renal Cell Carcinoma
}

\author{
Elyse Swallow, MPP; Andrew Messali, PharmD, PhD; Sameer Ghate, PhD; Evangeline McDonald, MPH; \\ Emilie Duchesneau, BA; and Jose Ricardo Perez, MD
}

\begin{abstract}
BACKGROUND: When considering optimal second-line treatments for metastatic renal cell carcinoma (mRCC), clinicians and payers seek to understand the relative clinical benefits and costs of treatment.

OBJECTIVE: To use an economic model to compare the additional cost per month of overall survival (OS) and of progression-free survival (PFS) for cabozantinib, nivolumab, and axitinib with everolimus for the second-line treatment of mRCC from a third-party U.S. payer perspective.

METHODS: The model evaluated mean OS and PFS and costs associated with drug acquisition/administration; adverse event (AE) treatment; monitoring; and postprogression (third-line treatment, monitoring, and end-of-life costs) over 1- and 2-year horizons. Efficacy, safety, and treatment duration inputs were estimated from regimens' pivotal clinical trials; for everolimus, results were weighted across trials. Mean 1- and 2-year OS and mean 1-year PFS were estimated using regimens' reported OS and PFS Kaplan-Meier curves. Dosing and administration inputs were consistent with approved prescribing information and the clinical trials used to estimate efficacy and safety inputs. Cost inputs came from published literature and public data. Additional cost per additional month of OS or PFS was calculated using the ratio of the cost difference per treated patient and the corresponding difference in mean OS or PFS between everolimus and each comparator. One-way sensitivity analyses were conducted by varying efficacy and cost inputs.
\end{abstract}

RESULTS: Compared with everolimus, cabozantinib, nivolumab, and axitinib were associated with $1.6,0.3$, and 0.5 additional months of PFS, respectively, over 1 year. Cabozantinib and nivolumab were associated with additional months of OS compared with everolimus (1 year: 0.7 and 0.8 months; 2 years: 1.6 and 2.3 months; respectively); axitinib was associated with fewer months ( 1 year: -0.2 months; 2 years: -0.7 months). The additional costs of treatment with cabozantinib, nivolumab, or axitinib versus everolimus over 1 year were $\$ 34,141, \$ 19,371$, and $\$ 17,506$ higher, respectively. Everolimus had similar OS and lower costs compared with axitinib. The additional cost per month of 0 S was $\$ 48,773$ for cabozantinib and $\$ 24,214$ for nivolumab versus everolimus. The additional treatment cost with cabozantinib, nivolumab, or axitinib versus everolimus for each additional month of PFS was estimated at $\$ 21,338, \$ 64,570$, and $\$ 35,012$, respectively. Over 2 years, the additional costs per additional month of $0 S$ for nivolumab and axitinib versus everolimus were similar to the 1-year analysis; for cabozantinib, the cost was lower. Results were sensitive to changes in mean OS, mean PFS, therapy duration, and drug costs estimates.

CONCLUSIONS: Everolimus for second-line mRCC was associated with similar OS and lower costs compared with axitinib over 1- and 2-year horizons. The additional cost per additional month of OS and PFS associated with cabozantinib or nivolumab versus everolimus creates a metric for evaluating the cost of second-line therapies in relation to their respective treatment effects.

J Manag Care Spec Pharm. 2018;24(4):335-43

Copyright $\odot 2018$, Academy of Managed Care Pharmacy. All rights reserved.

\section{What is already known about this subject}

Recently, cabozantinib and nivolumab were approved as secondline treatments for metastatic renal cell carcinoma (mRCC), in addition to everolimus and axitinib.

Each of these therapies is associated with different clinical benefits and treatment costs; cost and efficacy measures are both relevant to clinicians and payers when evaluating optimal second-line therapy.

Everolimus has been previously associated with lower lifetime costs compared with axitinib, although it has not been compared with newer second-line mRCC therapies.

\section{What this study adds}

Using an economic model, this study compared the costs and benefits of everolimus versus cabozantinib, nivolumab, and axitinib for second-line treatment of mRCC by assessing the additional cost per patient and costs per month of overall survival (OS) and progression-free survival (PFS) over 1- and 2-year horizons from a U.S payer perspective.

Everolimus had the lowest cost per treated patient, as well as the lowest costs per month of OS and PFS over 1- and 2-year horizons. Use of everolimus was associated with lower costs and longer OS than use of axitinib, and nivolumab and cabozantinib had higher costs and longer OS.

$\mathrm{R}$ enal cell carcinoma (RCC) is a common malignancy of the kidney among adults in the United States and represents $80 \%-85 \%$ of primary renal neoplasms. ${ }^{1,2}$ More than one quarter of patients present with metastatic RCC (mRCC) at diagnosis and up to half of those presenting with resectable disease eventually develop metastases. ${ }^{3-7}$ The 
prognosis for mRCC has historically been poor, with a 5-year survival rate of approximately $10 \% .{ }^{5}$ However, newer treatment strategies for RCC have resulted in an increase in the survival rate over the past few decades, despite a rise in RCC incidence. ${ }^{8}$

Sequential treatment with targeted therapies, including mammalian target of rapamycin inhibitors such as everolimus and vascular endothelial growth factor receptor tyrosine kinase inhibitors (VEGFR TKIs) such as axitinib, ${ }^{, 10}$ is routinely used for mRCC and has prolonged overall survival (OS) relative to cytokine treatment. ${ }^{3,10-14}$ In addition, 2 targeted therapies, cabozantinib (a TKI inhibitor) and nivolumab (a programmed cell death 1 inhibitor), were recently approved in the United States as monotherapy for mRCC in patients who received prior antiangiogenic therapy. ${ }^{15-17}$ Cabozantinib and nivolumab have been compared with everolimus in separate head-to-head clinical trials and have demonstrated clinical benefits. In the METEOR trial, ${ }^{18,19}$ cabozantinib was associated with a median progression-free survival (PFS) of 7.4 months, compared with everolimus's 3.8 months. In the CheckMate-025 trial, ${ }^{20}$ nivolumab was associated with a median OS of 25.0 months, compared with everolimus's 19.6 months.

With these new options, the treatment landscape for mRCC in the second-line treatment setting is rapidly evolving. As health care decision makers consider the optimal choice for second-line mRCC therapy, the available options may be considered in terms of patient outcomes as well as the costs associated with treatment. To evaluate the value of second-line mRCC therapies, it is necessary to account for both efficacy and costs-including costs related to the drug itself, administration and monitoring, and the treatment of adverse events (AEs).

Prior assessments of cost-effectiveness have noted the costeffectiveness of second-line everolimus over axitinib in the United States, ${ }^{21}$ Russia, ${ }^{22}$ and the United Kingdom ${ }^{23}$ but have not included newer targeted therapy comparators available in the United States. Thus, the objective of this study was to compare the relative costs and benefits of everolimus, cabozantinib, nivolumab, and axitinib for second-line treatment of mRCC by assessing the cost per treated patient, cost per month of OS, and cost per month of PFS over 1- and 2-year horizons from a U.S. payer perspective. In addition, this study assessed the additional cost per month of OS and PFS gained between everolimus and cabozantinib, nivolumab, and axitinib.

\section{Methods}

\section{Model Overview}

Both costs and efficacy measures are important when considering the optimal sequence of treatments for RCC. An economic model in Excel (Microsoft, Redmond, WA) was designed and implemented to compare the cost per treated patient, cost per month of OS, and cost per month of PFS for the following regimens: everolimus, cabozantinib, nivolumab, and axitinib. The study population was mRCC patients who had received at least 1 prior targeted therapy, and the model incorporated data from clinical trials (see next section) that enrolled patients who had received prior treatment for $\mathrm{mRCC}$.

The model was developed to reflect a U.S. third-party payer perspective. Costs and patient outcomes were calculated over 1- and 2-year horizons. One- and 2-year horizons were selected based on the following considerations: (a) Not all clinical trials used in the analysis reported PFS and OS information beyond 2 years; (b) median OS was less than 2 years for all arms other than nivolumab (which was 25.2 months); and (c) these time horizons are of particular interest to payers when considering the drugs to include on their formularies. Because of the modeling horizons, discount rates were not included in the analysis. Because most pivotal trials have not reported PFS data at 24 months of follow-up, we were unable to include the cost per month of PFS in the 2-year analysis.

The cost per treated patient included drug and drug administration costs, costs associated with the treatment of AEs, monitoring costs, and postprogression costs within the time horizon of the model. The calculation captured major medical costs for patients in the 1 or 2 years (depending on the time horizon) following initiation of second-line treatment. As many patients progress during these time intervals, subsequent treatment costs were considered in order to capture a full picture of medical costs. The costs per month of OS and of PFS were calculated by dividing the cost per treated patient by the average months of OS and average months of PFS, respectively, during the time horizon of the model for each comparator. Pairwise comparisons of everolimus versus the comparator regimens (cabozantinib, nivolumab, and axitinib) were conducted by calculating additional costs per treated patient, additional costs per additional month of OS, and additional costs per additional month of PFS. All costs were inflated to January 2016 U.S. dollars using the annual Consumer Price Index for All Urban Consumers, Medical Care (seasonally adjusted). ${ }^{24}$

\section{Efficacy and Safety Inputs}

Efficacy and safety inputs were identified from the pivotal trials for each comparator (RECORD-1, ${ }^{11}$ CheckMate-025, METEOR, AXIS, ${ }^{25}$ and Motzer et al. [2015] $\left.{ }^{26}\right)$. Data from patients treated with a prior targeted therapy (i.e., sunitinib) and randomized to axitinib were included from the AXIS trial. Efficacy and safety inputs for everolimus were based on weighted averages of results from the following randomized controlled trials that included everolimus as a study arm: RECORD-1, CheckMate-025, METEOR, and Motzer et al. ${ }^{26}$

For consistency, all efficacy parameters were gathered from randomized controlled trials (Appendix A, available in online article), and therefore a recent indirect treatment comparison of everolimus and axitinib was not included..$^{27}$ The efficacy inputs 
The Additional Costs per Month of Progression-Free Survival and Overall Survival: An Economic Model Comparing Everolimus with Cabozantinib, Nivolumab, and Axitinib for Second-Line Treatment of Metastatic Renal Cell Carcinoma

TABLE 1 Efficacy, Treatment Duration, Drug Cost, Administration Cost, and Third-Line Market Share Estimates

\begin{tabular}{|c|c|c|c|c|c|c|c|c|c|c|}
\hline \multirow[b]{2}{*}{ Regimen } & \multirow{2}{*}{$\begin{array}{c}\text { Mean } \\
\text { 1-Year } \\
\text { PFS } \\
\text { (Months) }\end{array}$} & \multicolumn{2}{|c|}{$\begin{array}{l}\text { Mean OS } \\
\text { (Months) }\end{array}$} & \multicolumn{2}{|c|}{$\begin{array}{l}\text { Mean } \\
\text { Treatment } \\
\text { Duration } \\
\text { (Weeks) }\end{array}$} & \multirow[b]{2}{*}{$\begin{array}{c}\text { Recommended } \\
\text { Dosing } \\
\text { Schedule }\end{array}$} & \multirow{2}{*}{$\begin{array}{c}\text { Drug and } \\
\text { Administration } \\
\text { Cost per Dose } \\
\$\end{array}$} & \multirow[b]{2}{*}{$\begin{array}{c}\text { Total } \\
\text { Treatment } \\
\text { Cost, } \$\end{array}$} & \multirow{2}{*}{$\begin{array}{l}\text { Third-Line } \\
\text { Market Share } \\
\text { for Patients } \\
\text { Following } \\
\text { Second-Line } \\
\text { Regimen, \%a }\end{array}$} & \multirow[b]{2}{*}{ Sources } \\
\hline & & $\underset{\beth}{\check{\beth}}$ & 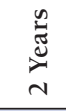 & 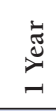 & 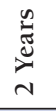 & & & & & \\
\hline Everolimus & 5.7 & 9.9 & 15.9 & 23 & 26 & $10 \mathrm{mg}$ OD & 402.31 & 61,955 & $\begin{array}{l}\text { axitinib: } 39 \\
\text { pazopanib: } 13 \\
\text { sunitinib: } 10 \\
\text { cabozantinib: } 1 \\
\text { nivolumab: } 11\end{array}$ & $\begin{array}{l}\text { Efficacy: RECORD-1,11 } \\
\text { CheckMate-025,20 METEOR, } 18,19 \\
\text { Motzer et al. }{ }^{26} \\
\text { Treatment duration: RECORD-1,11 } \\
\text { CheckMate-025,20 METEOR, }{ }^{18,19} \\
\text { Motzer et al. }{ }^{26} \\
\text { Dosing schedule: Afinitor PI }{ }^{31} \\
\text { Drug costs: ReadyPrice WAC } 32\end{array}$ \\
\hline Cabozantinib & 7.3 & 10.6 & 17.5 & 32 & 42 & $60 \mathrm{mg}$ OD & 458.33 & 99,458 & $\begin{array}{l}\text { axitinib: } 28 \\
\text { pazopanib: } 9 \\
\text { sunitinib: } 7 \\
\text { nivolumab: } 8 \\
\text { everolimus: } 21\end{array}$ & $\begin{array}{l}\text { Efficacy: METEOR } 18,19 \\
\text { Treatment duration: METEOR }{ }^{18,19} \\
\text { Dosing schedule: Cabometyx PI } 15 \\
\text { Drug costs: ReadyPrice WAC } 32\end{array}$ \\
\hline Nivolumab & 6 & 10.7 & 18.2 & 33 & 45 & $\begin{array}{l}3 \mathrm{mg} / \mathrm{kg} \text { IV infu- } \\
\text { sion over } 1 \text { hour, } \\
\text { every } 2 \text { weeks }\end{array}$ & $5,841.54$ & 77,713 & $\begin{array}{l}\text { axitinib: } 31 \\
\text { pazopanib: } 10 \\
\text { sunitinib: } 8 \\
\text { cabozantinib: } 1 \\
\text { everolimus: } 24\end{array}$ & $\begin{array}{l}\text { Efficacy: CheckMate- } 025^{20} \\
\text { Treatment duration: } \\
\text { CheckMate- } 025^{20} \\
\text { Dosing schedule: Opdivo PI } 16 \\
\text { Drug costs: ReadyPrice WAC } 32 \\
\text { Administration costs: CMS } \\
\text { Physician Fee Schedule } 33\end{array}$ \\
\hline Axitinib & 6.2 & 9.7 & 15.2 & 27 & 33 & $5 \mathrm{mg}$ BID & 198.85 & 72,382 & $\begin{array}{l}\text { pazopanib: } 14 \\
\text { sunitinib: } 11 \\
\text { cabozantinib: } 2 \\
\text { nivolumab: } 13 \\
\text { everolimus: } 34\end{array}$ & $\begin{array}{l}\text { Efficacy: AXIS } 25 \\
\text { Treatment duration: AXIS } 25 \\
\text { Dosing schedule: Inlyta PI } 34 \\
\text { Drug costs: ReadyPrice WAC } 32\end{array}$ \\
\hline
\end{tabular}

Note: All costs are in 2016 U.S. dollars.

aData on file. Novartis Pharmaceuticals Corporation. Internal market share data. 2016.

$B I D=$ twice daily; $C M S=$ Centers for Medicare $\&$ Medicaid Services; $I V=$ intravenous; $O D=$ once daily; OS= overall survival; $P F S=$ progression-free survival;

$\mathrm{PI}=$ prescribing information; $\mathrm{WAC}=$ wholesale acquisition cost

that were considered in the model were mean l-year and mean 2-year OS and mean 1-year PFS for each comparator (Table 1). Mean OS and PFS were calculated in R software package 3.2.2 (R Foundation, Vienna, Austria) by digitizing the Kaplan-Meier curves from each trial and reconstructing individual patient data using an algorithm by Guyot et al. (2012). ${ }^{28}$ This method calculated the restricted mean survival time, defined by the area under the curve up to a specified time (i.e., the time horizon). Median OS and PFS were not considered, as they were based on varying trial follow-up time periods and often exceeded the time horizon of the model.

The incidence of Grade 3 and 4 AEs (according to the definitions of the National Cancer Institute's Common Terminology Criteria for Adverse Events) with at least 5\% incidence in the arms of interest were derived from the pivotal clinical trials. ${ }^{29}$ A cutoff of 5\% was chosen because AEs with less than 5\% incidence were not reported for many of the clinical trials (i.e., CheckMate-025, RECORD-1, and METEOR). The AE input values are summarized in Table 2 .
The reporting criteria for AEs differed between studies: RECORD-1 and METEOR reported AEs irrespective of relation to treatment, whereas CheckMate-025, AXIS, and Motzer et al. reported treatment-emergent AEs (TEAEs). ${ }^{26}$ In order to ensure consistency between comparators, when comparing everolimus versus cabozantinib, we derived the proportion of patients experiencing each AE for everolimus from studies that reported any $\mathrm{AE}$, regardless of relation to treatment (RECORD-1 and METEOR). When comparing everolimus versus nivolumab or axitinib, we derived the proportions of AEs for everolimus from studies that reported TEAEs (CheckMate-025, AXIS, and Motzer et al. ${ }^{26}$ ). In both cases, the proportion of patients experiencing each AE for everolimus was estimated by taking a weighted average of the AE incidence reported in the everolimus study arm in each included clinical trial.

\section{Cost Inputs}

Please see the appendices (available in online article) for details of how drug and administration costs, AE costs, monitoring costs, and postprogression and end-of-life costs were calculated for use in the model. 
The Additional Costs per Month of Progression-Free Survival and Overall Survival: An Economic Model Comparing Everolimus with Cabozantinib, Nivolumab, and Axitinib for Second-Line Treatment of Metastatic Renal Cell Carcinoma

TABLE 2 Proportion of Patients Experiencing Grade 3 and 4 Adverse Events and Cost Parameter Estimates

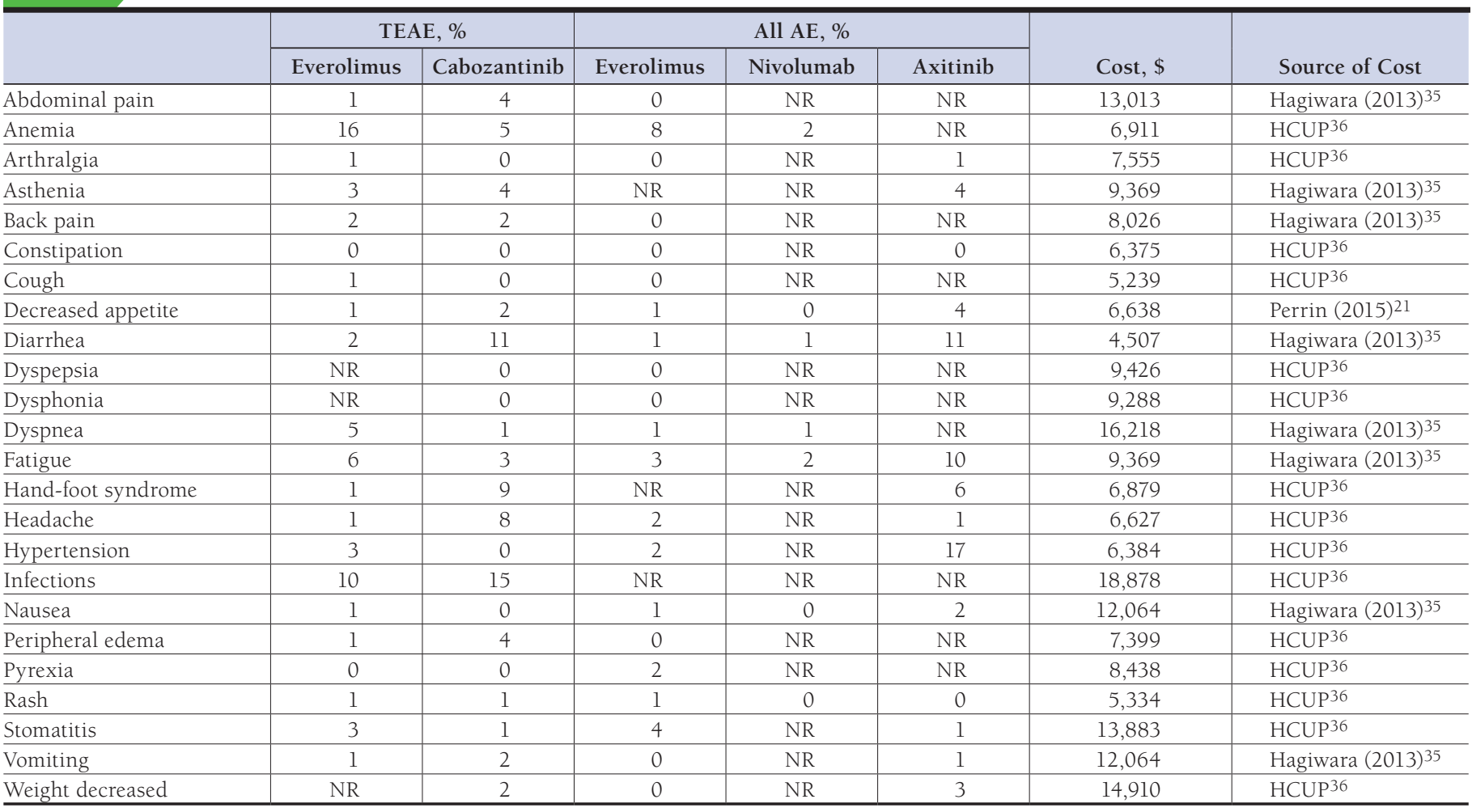

Note: All costs are in 2016 U.S. dollars.

$A E=$ adverse event $; C U P=$ Healthcare Cost and Utilization Project; $N R=$ not reported; TEAE = treatment-emergent adverse event.

\section{Sensitivity Analyses}

Univariate sensitivity analyses were performed for the 1-year horizon (the base case) to test the impact of each of the key modeling parameters on model outcomes. While keeping other inputs constant, we varied each model input around the base case analysis to determine the effect on the pairwise analyses of additional cost per additional month of OS and of PFS. Lower and upper estimates for the efficacy sensitivity analyses were obtained from the 95\% confidence intervals (CIs) of the mean OS and PFS. Drug acquisition costs were adjusted by $\pm 25 \%$ and using average wholesale prices as alternative cost estimates, where applicable. Treatment duration for each regimen was similarly adjusted by $\pm 25 \%$. This assumption was based on the duration of second targeted therapy for mRCC, which has an estimated median of 8.6 months, ranging from 4.4 months to 10.8 months. ${ }^{30}$

Postprogression costs were modified by adjusting the duration of third-line treatment by $25 \%$ from the duration reported in the prescribing information among treatments indicated for second-line use, and by 50\% among treatments indicated for first-line use. Other postprogression costs and costs associated with treating AEs were adjusted by $\pm 25 \%$.

\section{Results}

\section{Characteristics of Included Trials}

The average age across the trial cohorts ranged from 61 to 63 years, and approximately two thirds of patients were male (see Appendix A for the patient characteristics reported in the included trials). Although race was not reported in the RECORD-1 trial, across other trials, the racial distributions were similar (the vast majority of patients were white). The AXIS trial had a slightly higher proportion of Asian patients compared with the other trials. The distributions of patients across Memorial Sloan Kettering Cancer Center prognostic risk categories were also similar between trials, with a slightly higher proportion of patients in the METEOR trial having favorable risk scores compared with the other trials. The vast majority of patients in the RECORD-1, CheckMate-025, and METEOR trials had prior nephrectomy; the AXIS trial did not report the proportion of patients with prior nephrectomy.

\section{OS (1- and 2-Year) and PFS (1-Year) of Second-Line Therapies for mRCC Versus Everolimus}

Over a 1-year horizon, cabozantinib and nivolumab were associated with 0.7 and 0.8 additional months of OS, respectively, 
The Additional Costs per Month of Progression-Free Survival and Overall Survival: An Economic Model Comparing Everolimus with Cabozantinib, Nivolumab, and Axitinib for Second-Line Treatment of Metastatic Renal Cell Carcinoma

\section{FIGURE 1 Cost per Treated Patient over 1- and 2-Year Time Horizons}

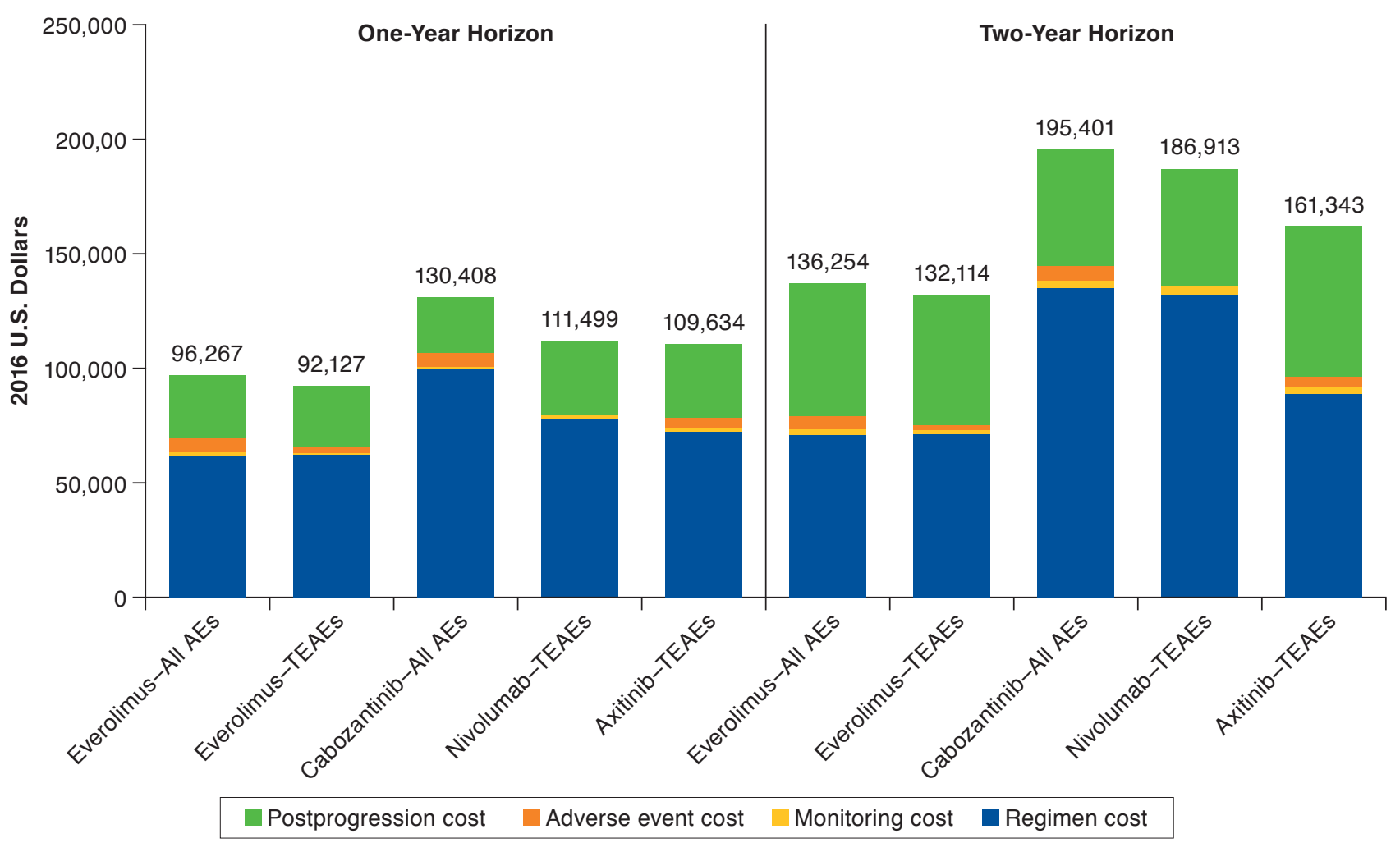

Note: Total annual treatment costs are listed above each therapy's respective bar

$A E=$ adverse event $; E A E=$ treatment-emergent adverse event.

whereas axitinib was associated with 0.2 fewer months of OS compared with everolimus. In terms of additional months of PFS over a l-year horizon, cabozantinib, nivolumab, and axitinib were associated with $1.6,0.3$, and 0.5 additional months, respectively, compared with everolimus. Over a 2-year horizon, cabozantinib and nivolumab were associated with 1.6 and 2.3 additional months of OS in comparison with everolimus, while axitinib was associated with 0.7 fewer months.

One-Year Analysis. Over the 1-year horizon, the cost per treated patient was estimated to be $\$ 92,127$ and $\$ 96,267$ for everolimus when considering only TEAEs or all AEs, respectively (Figure 1). The comparative costs were $\$ 130,408$ for cabozantinib, which included only TEAEs, and $\$ 109,634$ for axitinib and \$111,499 for nivolumab, which considered all AEs. Regimen costs were the largest component of costs for all treatments (64.4\%-76.3\%), with cabozantinib having the highest $(\$ 99,458)$ and everolimus having the lowest $(\$ 61,955)$ regimen costs over a 1-year horizon.

Postprogression costs represented the second-largest component of costs (18.4\%-30.0\%) and were similar in amount among the comparators ( $\$ 23,990$ [cabozantinib] to $\$ 32,824$ [nivolumab]). The contribution of monitoring costs (0.3\%$0.4 \%)$ and $\mathrm{AE}$ costs $(0.6 \%-6.7 \%)$ to the total were relatively small compared with the other cost components, for all comparators. Everolimus had a lower cost per month of OS $(\$ 9,306)$ and lower cost per month of PFS $(\$ 16,163)$ than the other comparators (Table 3). After everolimus, nivolumab had the next lowest cost per month of OS $(\$ 10,420)$ and axitinib had the next lowest cost per month of PFS $(\$ 17,683)$.

The additional cost per treated patient compared with everolimus was $\$ 34,141$ for cabozantinib, $\$ 19,371$ for nivolumab, and $\$ 17,506$ for axitinib over the 1-year horizon. For each additional month of OS, the cost per patient was estimated to be $\$ 48,773$ for cabozantinib and $\$ 24,214$ for nivolumab compared with treatment with everolimus. With respect to cost per months of OS, everolimus dominated axitinib (i.e., had longer OS as well as lower costs). For each additional month of PFS, the additional cost per patient, compared with treatment with everolimus, was $\$ 21,338$ for cabozantinib, $\$ 64,570$ for nivolumab, and $\$ 35,012$ for axitinib. 


\begin{tabular}{|c|c|c|c|c|c|}
\hline \multirow[b]{3}{*}{ Cost, \$ } & \multicolumn{5}{|c|}{$\begin{array}{l}\text { Cost per Treated Patient, Cost per } \\
\text { Month of PFS, and Cost per Month of } \\
\text { OS over 1- and 2-Year Time Horizons }\end{array}$} \\
\hline & \multicolumn{2}{|c|}{$\begin{array}{c}\text { Regimens Reporting } \\
\text { All AEs } \\
\end{array}$} & \multicolumn{3}{|c|}{ Regimens Reporting TEAEs } \\
\hline & Everolimus & Cabozantinib & Everolimus & Nivolumab & Axitinib \\
\hline \multicolumn{6}{|c|}{ Cost per patient per month of PFS } \\
\hline 1 year & 16,889 & 17,864 & 16,163 & 18,583 & 17,683 \\
\hline \multicolumn{6}{|c|}{ Cost per patient per month of OS } \\
\hline 1 year & 9,724 & 12,303 & 9,306 & 10,420 & 11,302 \\
\hline 2 years & 8,569 & 11,166 & 8,309 & 10,270 & 10,615 \\
\hline
\end{tabular}

Two-Year Analysis. Similar to the 1-year analysis, everolimus had the lowest cost per treated patient $(\$ 136,254$ [all AEs] and $\$ 132,114$ [only TEAEs]) compared with cabozantinib $(\$ 195,401)$, nivolumab $(\$ 186,913)$, and axitinib (\$161,343; Figure 1). Also similar to the 1-year results, regimen costs were the largest component of costs for all treatments compared, with cabozantinib having the highest regimen costs over the 2-year horizon.

Postprogression costs continued to represent the second largest component of costs and were similar across all comparators, and monitoring costs and $\mathrm{AE}$ costs were small contributors to the total costs compared with the other cost components. Everolimus had a lower cost per month of OS, $\$ 8,569$ when considering all AEs, compared with cabozantinib (\$11,166; Table 3). Everolimus also had a lower cost per month of OS, including only TEAEs $(\$ 8,309)$, compared with nivolumab $(\$ 10,270)$ and axitinib $(\$ 10,615)$.

The additional cost per treated patient compared with everolimus was $\$ 59,147$ for cabozantinib, $\$ 54,799$ for nivolumab, and $\$ 29,229$ for axitinib over the 2-year horizon. Compared with everolimus, the additional cost per patient was estimated to be $\$ 36,967$ for cabozantinib and $\$ 23,826$ for nivolumab for each additional month of OS. As in the 1-year analysis, everolimus dominated axitinib.

\section{Sensitivity Analyses}

To determine the impact of varying model inputs for the base case, univariate sensitivity analyses were performed for the l-year horizon. The results of the sensitivity analyses were fairly consistent when adjusting model inputs from the base case and were sensitive to changes in the estimates for mean OS, mean PFS, duration of therapy, and drug costs. The lowest additional cost per patient receiving cabozantinib, nivolumab, or axitinib versus everolimus was estimated to be $\$ 12,106$, $\$ 483$, and $\$ 2,947$, respectively, for each additional month of OS (Table 4), and $\$ 5,296, \$ 1,287$, and $\$ 1,605$, respectively, for each additional month of PFS (Appendix B, available in online article). The highest additional cost per patient receiving cabozantinib or nivolumab versus everolimus was estimated to be $\$ 154,748$ and $\$ 53,933$, respectively, for each additional month of OS (Table 4). In most sensitivity analyses comparing everolimus to axitinib, everolimus dominated axitinib in terms of OS. The highest additional cost per patient versus everolimus was estimated to be $\$ 33,284$ for cabozantinib, $\$ 127,854$ for nivolumab, and $\$ 71,203$ for axitinib for each additional month of PFS (Appendix B).

\section{Discussion}

This model assessed the relative costs and benefits of everolimus versus axitinib, nivolumab, and cabozantinib for the second-line treatment of mRCC. Incorporating both costs and efficacy associated with second-line mRCC treatments into a simple metric may be useful to both clinicians and payers assessing the value of second-line treatment options. This study is focused on the United States where, historically, evaluations using methods such as incremental cost per quality of life-years (e.g., incremental cost-effectiveness ratio) are less common compared with other regions. Thus, we created a metric that incorporates cost per month of survival to provide U.S. payers more information regarding the total costs associated with each of the treatments, as well as the costs in terms of the efficacy benefits.

The intent is not to guide toward 1 treatment choice over another, but to provide new information that quantifies the tradeoff between additional months of survival and additional costs. There are 2 main benefits of combining efficacy and cost information into a metric such as the cost per month of OS or cost per month of PFS: (a) This allows treatments to be compared with one another on a common scale; and (b) audiences can interpret these metrics using their own willingness to pay for a month of OS or a month of PFS.

To our knowledge, there have been no prior estimates of the additional cost per month of OS or PFS among secondline monotherapies for mRCC available in the United States. However, the current finding that second-line mRCC treatment with everolimus was associated with lower costs and longer OS than axitinib is generally consistent with a previously published economic model assessing the cost-effectiveness of these treatments in the United States. Perrin et al. (2015) used a Markov model to estimate the lifetime cost per patient for sunitinib-refractory patients with mRCC using secondline everolimus versus axitinib from a U.S. payer perspective and found that treatment with axitinib was about $11 \%$ more expensive than everolimus. ${ }^{21}$ Specifically, the total costs over a 10.6-year horizon were estimated to be $\$ 104,226$ for everolimus and \$117,211 for axitinib (2014 dollars). Adjusted to 2016 dollars, these values are equivalent to $\$ 109,437$ for everolimus and $\$ 123,082$ for axitinib. 
TABLE 4 Sensitivity of Incremental Cost per Month of OS

\begin{tabular}{|c|c|c|c|c|c|c|}
\hline \multirow[b]{2}{*}{ Parameter } & \multicolumn{2}{|c|}{$\begin{array}{l}\text { Everolimus vs. } \\
\text { Cabozantinib, \$ }\end{array}$} & \multicolumn{2}{|c|}{ Everolimus vs. Nivolumab, \$ } & \multicolumn{2}{|c|}{ Everolimus vs. Axitinib, \$ } \\
\hline & Low Value & High Value & Low Value & High Value & Low Value & High Value \\
\hline Base case & \multicolumn{2}{|c|}{48,773} & \multicolumn{2}{|l|}{24,214} & \multicolumn{2}{|c|}{ Everolimus has lower costs and greater efficacy } \\
\hline $\begin{array}{l}\text { Everolimus PFS, } \\
\text { bounds of } 95 \% \text { CI }\end{array}$ & 44,255 & 52,304 & 20,261 & 27,304 & $\begin{array}{l}\text { Everolimus has lower } \\
\text { costs and greater efficacy }\end{array}$ & $\begin{array}{l}\text { Everolimus has lower costs } \\
\text { and greater efficacy }\end{array}$ \\
\hline $\begin{array}{l}\text { Comparator PFS, } \\
\text { bounds of } 95 \% \text { CI }\end{array}$ & 44,529 & 42,073 & 20,946 & 27,482 & $\begin{array}{l}\text { Everolimus has lower } \\
\text { costs and greater efficacy }\end{array}$ & $\begin{array}{l}\text { Everolimus has lower costs } \\
\text { and greater efficacy }\end{array}$ \\
\hline $\begin{array}{l}\text { Everolimus OS, } \\
\text { bounds of } 95 \% \mathrm{CI}\end{array}$ & 33,310 & 154,748 & 18,226 & 53,933 & 100,034 & $\begin{array}{l}\text { Everolimus has lower costs } \\
\text { and greater efficacy }\end{array}$ \\
\hline $\begin{array}{l}\text { Comparator OS, } \\
\text { bounds of } 95 \% \text { CI }\end{array}$ & 81,601 & 34,196 & $\begin{array}{l}\text { Everolimus has lower } \\
\text { costs and greater efficacy }\end{array}$ & 21,523 & $\begin{array}{l}\text { Everolimus has lower } \\
\text { costs and greater efficacy }\end{array}$ & 53,543 \\
\hline Everolimus WAC price, $\pm 25 \%$ & 70,900 & 26,646 & 43,575 & 4,853 & $\begin{array}{l}\text { Everolimus has lower } \\
\text { costs and greater efficacy }\end{array}$ & $\begin{array}{l}\text { Everolimus has lower costs } \\
\text { and greater efficacy }\end{array}$ \\
\hline Comparator WAC price, $\pm 25 \%$ & 34,564 & 62,981 & 483 & 47,945 & 2,947 & $\begin{array}{l}\text { Everolimus has lower costs } \\
\text { and greater efficacy }\end{array}$ \\
\hline AWP prices & 59,488 & - & 27,710 & - & $\begin{array}{l}\text { Everolimus has lower } \\
\text { costs and greater efficacy }\end{array}$ & - \\
\hline $\begin{array}{l}\text { Everolimus treatment } \\
\text { duration, } \pm 25 \%\end{array}$ & 72,911 & 40,727 & 45,335 & 17,174 & $\begin{array}{l}\text { Everolimus has lower } \\
\text { costs and greater efficacy }\end{array}$ & $\begin{array}{l}\text { Everolimus has lower costs } \\
\text { and greater efficacy }\end{array}$ \\
\hline $\begin{array}{l}\text { Comparator treatment } \\
\text { duration, } \pm 25 \%\end{array}$ & 12,106 & 48,773 & 16,741 & 24,214 & $\begin{array}{l}\text { Everolimus has lower } \\
\text { costs and greater efficacy }\end{array}$ & $\begin{array}{l}\text { Everolimus has lower costs } \\
\text { and greater efficacy }\end{array}$ \\
\hline $\begin{array}{l}\text { Other postprogression costs, } \\
\pm 25 \%\end{array}$ & 48,852 & 48,694 & 24,179 & 24,249 & $\begin{array}{l}\text { Everolimus has lower } \\
\text { costs and greater efficacy }\end{array}$ & $\begin{array}{l}\text { Everolimus has lower costs } \\
\text { and greater efficacy }\end{array}$ \\
\hline $\begin{array}{l}\text { Duration of third-line } \\
\text { treatment, } \pm 50 \% \text { or } \pm 25 \%\end{array}$ & 49,951 & 48,773 & 19,856 & 24,214 & $\begin{array}{l}\text { Everolimus has lower } \\
\text { costs and greater efficacy }\end{array}$ & $\begin{array}{l}\text { Everolimus has lower costs } \\
\text { and greater efficacy }\end{array}$ \\
\hline Cost of adverse events, $\pm 25 \%$ & 48,737 & 48,808 & 24,741 & 23,687 & $\begin{array}{l}\text { Everolimus has lower } \\
\text { costs and greater efficacy }\end{array}$ & $\begin{array}{l}\text { Everolimus has lower costs } \\
\text { and greater efficacy }\end{array}$ \\
\hline
\end{tabular}

Note: All costs are in 2016 U.S. dollars.

$A W P=$ average wholesale price; $C I=$ confidence interval; $O S=$ overall survival; $P F S=$ progression-free survival; $W A C=$ wholesale acquisition cost.

Despite the longer time horizon, these estimates are roughly $25 \%$ lower than the 2-year estimates reported here, due to several differences between the assessment methods used by that study and the current study. First, Perrin et al. assumed that the treatment duration for axitinib users was 1 month shorter than in the present analysis, which resulted in a lower axitinib treatment cost. Second, Perrin et al. included deviations from the dosing schedule recommended in product prescribing information by modeling dose intensity reported in the therapies' respective clinical trials. This methodology had the effect of lowering treatment costs for everolimus. Third, Perrin et al. derived inputs for postprogression treatment costs from clinical trial documents, whereas we used recent third-line mRCC market share data, which may be more representative of realworld treatment patterns. These different sources resulted in Perrin et al.'s estimates of postprogression costs after everolimus or axitinib failure to be roughly $\$ 30,000$ less than in the present analysis.

In terms of incremental costs per additional month of OS, the sensitivity analysis comparing everolimus with cabozantinib, nivolumab, and axitinib was most sensitive to changes in the following: the OS associated with everolimus and the comparator, the WAC price of the drugs, and the duration of treatment. Similar results were observed for incremental costs per additional month of PFS (with the model being sensitive to the PFS associated with everolimus and the comparator, as well as the other items mentioned). Everolimus remained dominant over axitinib in most scenarios in the sensitivity analysis of incremental costs per month of OS. When the OS of nivolumab was adjusted to the lower bound of its $95 \% \mathrm{CI}$, everolimus was dominant in terms of incremental cost per month of OS. When the PFS of everolimus was modified to the upper bound of its 95\% CI, or the PFS of nivolumab or axitinib was modified to its lower bound, everolimus was dominant in terms of increment cost per month of PFS. Finally, axitinib was dominant over everolimus in the sensitivity analysis of incremental cost of additional month of PFS when the WAC price of axitinib was adjusted down by $25 \%$.

\section{Limitations}

The results of this study should be considered in light of its limitations. The cost per outcome model used inputs from clinical trials to estimate mean OS and PFS, mean duration of treatment, and incidence of AEs. Only AEs with a prevalence of $5 \%$ were included in the analysis. As only a small part of total costs is attributable to AEs, it is unlikely that AEs with 
an incidence lower than 5\% would have a large impact on the current model's results and conclusions.

In addition, the clinical trials used to derive the incidence of AEs used varying criteria to report AEs. The current model attempted to account for this by estimating the costs of AEs based on trials reporting TEAEs versus all AEs in separate analyses and only including studies with similar reporting criteria in the pairwise comparisons. The model did not account for differences between the trial populations used to calculate efficacy parameters; however, the demographic profiles between the studies were generally similar, although some differences were present (Appendix A). Only head-to-head comparative trials can overcome this limitation; such studies would be useful for the future. The current analysis used efficacy data from the AXIS subgroup of patients previously treated with sunitinib; however, the characteristics of this subpopulation are unknown. Dose intensity was not included as a parameter in this model, as the relative dose intensity was only reported in the AXIS trial publication.

The inclusion and exclusion criteria in the trials were also similar. One notable difference between the trials was prior exposure to mRCC treatment. RECORD-1, CheckMate-025, and METEOR all allowed patients to receive more than 1 prior treatment before study entry, while AXIS was conducted among patients who had received only 1 prior therapy (sunitinib or a cytokine). The majority of patients in the RECORD-1 and METEOR trials had only 1 prior VEGFR TKI, and the majority of patients in the CheckMate-025 trial had only 1 prior antiangiogenic regimen. Across all trials, the majority of patients were previously treated with sunitinib (range: 54\%-71\%). Comparability of other previous therapies could not be determined due to differences in reporting criteria.

Patient characteristics in each of the trials may also differ from real-world clinical populations. As such, the generalizability of these results may be limited. In addition, the mean OS and PFS over the modeling time horizons were estimated by digitalizing published Kaplan-Meier curves, as only median OS and median PFS were reported in the publications for the pivotal trials. However, estimating the mean survival time from reconstructed individual patient data using Kaplan-Meier curves is a well-accepted statistical method that allowed for costs and efficacy measures to be calculated over the same time horizon in the cost per month of OS and cost per month of PFS analyses. ${ }^{28}$

To use all available clinical trial data, efficacy inputs (mean OS and PFS) for everolimus were estimated using weighted averages of the RECORD-1, CheckMate-025, and METEOR trials. The estimated mean OS and PFS of the everolimus arms from the CheckMate-025 and METEOR trials were greater than the estimated mean OS and PFS from the RECORD-1 trial; therefore, the weighted average OS and PFS used in this model are conservative estimates for everolimus, compared with an analysis that only considered head-to-head data.
Finally, market share estimates for third-line therapies were based on market research that was not specific to the second-line treatment received. In order to account for this, market share estimates were adjusted under the assumption that patients could not receive the same treatment in third-line treatment that was received in second-line. The duration of third-line therapy was based on prescribing information. For therapies approved for first- and second-line treatment of mRCC, duration of therapy reported in the product labels may not accurately reflect the duration of therapy of third-line treatment.

\section{Conclusions}

Treatment with second-line everolimus for mRCC was associated with lower costs and longer OS than axitinib over both 1- and 2-year horizons; 1-year PFS was slightly longer (0.5 months) with axitinib. Additionally, everolimus was associated with lower costs per month of OS and lower costs per month of PFS than cabozantinib and nivolumab, although 1- and 2-year OS was longer with these drugs versus everolimus. The results of this study may be helpful in assessing the comparative costs and benefits of the available second-line treatments for patients with mRCC.

\section{Authors}

ELYSE SWALLOW, MPP; ANDREW MESSALI, PharmD, PhD; EVANGELINE MCDONALD, MPH; and EMILIE DUCHESNEAU, BA, Analysis Group, Boston, Massachusetts. SAMEER GHATE, PhD, and JOSE RICARDO PEREZ, MD, Novartis Pharmaceuticals, East Hanover, New Jersey.

AUTHOR CORRESPONDENCE: Elyse Swallow, MPP,

111 Huntington Ave., 14th Fl., Boston, MA 02199.

Tel.: 617.425.8483; E-mail: elyse.swallow@analysisgroup.com.

\section{DISCLOSURES}

Funding for this research was provided by Novartis, which was involved in all stages of study research and manuscript preparation. Ghate and Perez are employees of Novartis and own stock/stock options. Swallow, Messali, McDonald, and Duchesneau are employees of Analysis Group, which has received consultancy fees from Novartis

Study concept and design were contributed by Swallow, Messali, Ghate, and Perez, along with McDonald and Duchesneau. Swallow, Messali, McDonald, and Duchesneau collected the data, and all authors participated in data interpretation. The manuscript was written by Swallow, Messali, and Ghate, along with the other authors, and revised by Swallow, Messali, Ghate, and Perez.

A synopsis of the current research was presented in poster format at the 15th International Kidney Cancer Symposium on November 4-5, 2016, in Miami, Florida.

\section{ACKNOWLEDGMENTS}

Medical writing assistance was provided by Shelley Batts, $\mathrm{PhD}$, an employee of Analysis Group. 


\section{REFERENCES}

1. Siegel R, Naishadham D, Jemal A. Cancer statistics, 2013. CA Cancer J Clin. 2013;63(1):11-30

2. Choueiri TK. Prognostic factors in patients with renal cell carcinoma. In: Richie JP, Atkins MB, Ross ME, eds. UpToDate. 2015. Updated January 8, 2018.

3. Flanigan RC, Campbell SC, Clark JI, Picken MM. Metastatic renal cell carcinoma. Curr Treat Options Oncol. 2003;4(5):385-90.

4. Gupta K, Miller JD, Li JZ, Russell MW, Charbonneau C. Epidemiologic and socioeconomic burden of metastatic renal cell carcinoma (mRCC): a literature review. Cancer Treat Rev. 2008;34(3):193-205.

5. Lam J, Leppert J, Belldegrun A, Figlin R. Novel approaches in the therapy of metastatic renal cell carcinoma. World J Urol. 2005;23:202-12.

6. Motzer RJ, Bander NH, Nanus DM. Renal-cell carcinoma. N Engl J Med. 1996;335(12):865-75.

7. Janzen NK, Kim HL, Figlin RA, Belldegrun AS. Surveillance after radical or partial nephrectomy for localized renal cell carcinoma and management of recurrent disease. Urol Clin North Am. 2003;30(4):843-52.

8. American Cancer Society. Key statistics about kidney cancer. 2016. Updated January 4, 2018. Available at: http://www.cancer.org/cancer/kidneycancer/ detailedguide/kidney-cancer-adult-key-statistics. Accessed March 5, 2018.

9. Motzer RJ, Escudier B, Oudard S, et al. Efficacy of everolimus in advanced renal cell carcinoma: a double-blind, randomised, placebo-controlled phase III trial. Lancet. 2008;372(9637):449-56.

10. Rini BI, Escudier B, Tomczak P, et al. Comparative effectiveness of axitinib versus sorafenib in advanced renal cell carcinoma (AXIS): a randomised phase 3 trial. Lancet. 2011;378(9807):1931-39.

11. Motzer RJ, Escudier B, Oudard S, et al. Phase 3 trial of everolimus for metastatic renal cell carcinoma: final results and analysis of prognostic factors. Cancer. 2010;116(18):4256-65.

12. Randall JM, Millard F, Kurzrock R. Molecular aberrations, targeted therapy, and renal cell carcinoma: current state-of-the-art. Cancer Metastasis Rev. 2014;33(4):1109-24.

13. Pal SK, Nelson RA, Vogelzang N. Disease-specific survival in de novo metastatic renal cell carcinoma in the cytokine and targeted therapy era. PLoS One. 2013;8(5):e63341.

14. National Comprehensive Cancer Network. NCCN Clinical Practice Guidelines in Oncology: Kidney Cancer v. 3. 2015. Available at: https:// www.nccn.org/professionals/physician_gls/pdf/kidney.pdf. Accessed March 5, 2018

15. Cabometyx (cabozantinib) for oral use. Exelixis. 2012. Available at: http://www.accessdata.fda.gov/drugsatfda_docs/label/2016/208692s000lbl. pdf. Accessed October 10, 2016.

16. Opdivo (nivolumab) for intravenous use. Bristol Myers Squibb. 2014 Available at: http://packageinserts.bms.com/pi/pi_opdivo.pdf. Accessed March 5, 2018.

17. U.S. Food and Drug Administration. Drugs@FDA. FDA Approved Drug Products: Nivolumab. Available at: https://www.accessdata.fda.gov/scripts/ cder/daf/index.cfm?event=overview.process\&varApplNo=125554. Accessed March 19, 2018.

18. Choueiri TK, Escudier B, Powles T, et al. Cabozantinib versus everolimus in advanced renal-cell carcinoma. N Engl J Med. 2015;373(19):1814-23.

19. Choueiri TK, Powles T, Escudier B, et al., eds. Overall survival in METEOR, a randomized phase 3 trial of cabozantinib versus everolimus in patients with advanced renal cell carcinoma. Presented at: ASCO Annual Meeting; June 3-7, 2016; Chicago, IL.
20. Motzer RJ, Escudier B, McDermott DF, et al. Nivolumab versus everolimus in advanced renal-cell carcinoma. N Engl J Med. 2015;373(19):1803-13.

21. Perrin A, Sherman S, Pal S, et al. Lifetime cost of everolimus vs axitinib in patients with advanced renal cell carcinoma who failed prior sunitinib therapy in the US. J Med Econ. 2015;18(3):200-09.

22. Kolbin A, Frolov M, Kurylev A, Balykina Y, Proskurin M. Pharmacoeconomic analysis of the use of everolimus compared to axitinib in second line therapy of patients with metastatic renal cell carcinoma. Value Health. 2015;18(7):A442.

23. Chandiwana D, Perrin A, Sherman S. A cost effectivness analysis of everolimus compared with axitinib in the treatment of metastatic renal cell carcinoma in the United Kingdom. Value Health. 2014;17(7):A640.

24. U.S. Bureau of Labor Statistics. Consumer Price Index for All Urban Consumers. Medical care component (dataset). 2016. Available at: https:// data.bls.gov/timeseries/CUUR0000SAM?output_view=pct_12mths. Accessed March 15, 2018

25. Motzer RJ, Escudier B, Tomczak P, et al. Axitinib versus sorafenib as second-line treatment for advanced renal cell carcinoma: overall survival analysis and updated results from a randomised phase 3 trial. Lancet Oncol. 2013;14(6):552-62.

26. Motzer RJ, Hutson TE, Glen H, et al. Lenvatinib, everolimus, and the combination in patients with metastatic renal cell carcinoma: a randomised, phase 2, open-label, multicentre trial. Lancet Oncol. 2015;16(15):1473-82.

27. Sherman S, Amzal B, Calvo E, et al. An indirect comparison of everolimus versus axitinib in US patients with advanced renal cell carcinoma in whom prior sunitinib therapy failed. Clin Ther. 2015;37(11):2552-59.

28. Guyot P, Ades AE, Ouwens MJ, Welton NJ. Enhanced secondary analysis of survival data: reconstructing the data from published Kaplan-Meier survival curves. BMC Med Res Methodol. 2012;12:9.

29. National Cancer Institute. Common Terminology Criteria for Adverse Events (CTCAE). Version 4.0. 2009. Available at: https://www.acrin. org/Portals/0/Administration/Regulatory/CTCAE_4.02_2009-09-15_ QuickReference_5x7.pdf. Accessed March 5, 2018.

30. Jonasch E, Signorovitch JE, Lin PL, et al. Treatment patterns in metastatic renal cell carcinoma: a retrospective review of medical records from U.S. community oncology practices. Curr Med Res Opin. 2014;30(10):2041-50.

31. Afinitor (everolimus) for oral use. Novartis. 2009. Available at: http:// www.accessdata.fda.gov/drugsatfda_docs/label/2010/022334s6lbl.pdf. Accessed March 5, 2018.

32. Truven Health Analytics. RED BOOK Online (dataset). February 2, 2016. Available at: truvenhealth.com/products/micromedex/product-suites/ clinical-knowledge/redbook. Accessed March 15, 2018.

33. Centers for Medicare \& Medicaid Services. Physician fee schedule. February 26, 2016. Available at: https://www.cms.gov/Medicare/MedicareFee-for-Service-Payment/PhysicianFeeSched/index.html. Accessed March 15, 2018.

34. Inlyta (axitinib) for oral use. Pfizer. 2012. Available at: http://www. accessdata.fda.gov/drugsatfda_docs/label/2012/202324lbl.pdf. Accessed March 5, 2018.

35. Hagiwara M, Borker R, Oster G. Economic burden of adverse events in patients with metastatic renal cell carcinoma. Clin Ther. 2013;35(12):1955-63 e2.

36. Agency for Healthcare Research and Quality. HCUP Nationwide Inpatient Sample (NIS). 2013. February 24, 2016. Available at: https://www. hcup-us.ahrq.gov/databases.jsp. Accessed March 15, 2018

37. Heng DYC, Xie W, Regan MM, et al. Prognostic factors for overall survival in patients with metastatic renal cell carcinoma treated with vascular endothelial growth factor-targeted agents: results from a large, multicenter study. J Clin Oncol. 2009;27(34):5794-99. 
The Additional Costs per Month of Progression-Free Survival and Overall Survival: An Economic Model Comparing Everolimus with Cabozantinib, Nivolumab, and Axitinib for Second-Line Treatment of Metastatic Renal Cell Carcinoma

\section{APPENDIX A Baseline Characteristics Reported in Select mRCC Trials}

\begin{tabular}{|c|c|c|c|c|c|c|}
\hline \multirow[b]{2}{*}{ Characteristic } & \multirow{2}{*}{$\begin{array}{c}\text { RECORD-1 }^{11} \\
\text { Everolimus } \\
(\mathrm{n}=277)\end{array}$} & \multicolumn{2}{|c|}{ CheckMate- $025^{20}$} & \multicolumn{2}{|c|}{ METEOR $^{18,19}$} & \multirow{2}{*}{$\begin{array}{l}\text { AXIS10 } \\
\begin{array}{l}\text { Axitinib } \\
(n=361)\end{array}\end{array}$} \\
\hline & & $\begin{array}{l}\text { Nivolumab } \\
(n=410)\end{array}$ & $\begin{array}{l}\text { Everolimus } \\
\quad(n=411)\end{array}$ & $\begin{array}{c}\text { Cabozantinib } \\
(\mathbf{n}=330)\end{array}$ & $\begin{array}{l}\text { Everolimus } \\
(\mathbf{n}=328)\end{array}$ & \\
\hline Age, years & 61 & 62 & 62 & 63 & 62 & 61 \\
\hline Male, \% & 78 & 77 & 74 & 77 & 73 & 73 \\
\hline \multicolumn{7}{|c|}{ Geographic region, \% } \\
\hline Europe & NR & NR & NR & 54 & 47 & NR \\
\hline North America & & & & 36 & 37 & \\
\hline Asia-Pacific & & & & 12 & 14 & \\
\hline Latin America & & & & 2 & 2 & \\
\hline \multicolumn{7}{|l|}{ Race, $\%$} \\
\hline White & NR & 86 & 89 & 82 & 80 & 77 \\
\hline Asian & & 10 & 8 & 6 & 8 & 21 \\
\hline Black & & $<1$ & 1 & 2 & $<1$ & $<1$ \\
\hline Other & & 3 & 2 & 6 & 4 & 1 \\
\hline Not reported & & & & 5 & 7 & \\
\hline Missing data & & & & 0 & $<1$ & \\
\hline \multicolumn{7}{|c|}{ ECOG performance-status score, \% } \\
\hline 0 & NR & NR & NR & 68 & 66 & 54 \\
\hline 1 & & & & 32 & 34 & 45 \\
\hline$>1$ & & & & & & $<1$ \\
\hline \multicolumn{7}{|c|}{ MSKCC prognostic risk category, \% } \\
\hline Favorable & 29 & 35 & 36 & 45 & 46 & 28 \\
\hline Intermediate & 56 & 49 & 49 & 42 & 41 & 37 \\
\hline Poor & 14 & 16 & 15 & 12 & 13 & 33 \\
\hline NA & & & & & & 2 \\
\hline \multicolumn{7}{|l|}{ KPS, \% } \\
\hline 100 & 28 & 31 & 33 & & & \\
\hline 90 & 35 & 37 & 32 & NR & NR & NR \\
\hline 80 & 26 & 27 & 28 & & & \\
\hline 70 & 10 & 5 & 7 & & & \\
\hline$<70$ & & $<1$ & $<1$ & & & \\
\hline Missing data & $<1$ & & & & & \\
\hline \multicolumn{7}{|c|}{ Heng $(2009)^{37}$ risk factors } \\
\hline Favorable & & & & & & 18 \\
\hline Intermediate & NR & NR & NR & NR & NR & 65 \\
\hline Poor & & & & & & 10 \\
\hline $\mathrm{NA}$ & & & & & & 6 \\
\hline \multicolumn{7}{|c|}{ Prior VEGFR TKIs, \% } \\
\hline 1 & 74 & NR & NR & 71 & 70 & NR \\
\hline$\geq 2$ & 26 & & & 29 & 30 & \\
\hline \multicolumn{7}{|l|}{ Previous therapy, \% } \\
\hline Sunitinib & 71 & 60 & 59 & 64 & 62 & 54 \\
\hline Pazopanib & & 29 & 32 & 44 & 41 & \\
\hline Axitinib & & 12 & 12 & 16 & 17 & \\
\hline Sorafenib & 55 & & & 6 & 9 & \\
\hline Bevacizumab & & & & 2 & 3 & 8 \\
\hline Interleukin-2 & & & & 6 & 9 & \\
\hline Interferon $a$ & & & & 6 & 7 & \\
\hline Nivolumab & & & & 5 & 4 & \\
\hline Cytokines & & & & & & 35 \\
\hline Temsirolimus & & & & & & 3 \\
\hline Immunotherapy & 65 & & & & & \\
\hline Chemotherapy & 13 & & & & & \\
\hline Hormone therapy & 2 & & & & & \\
\hline Other & 5 & & & & & \\
\hline
\end{tabular}


The Additional Costs per Month of Progression-Free Survival and Overall Survival: An Economic Model Comparing Everolimus with Cabozantinib, Nivolumab, and Axitinib for Second-Line Treatment of Metastatic Renal Cell Carcinoma

APPENDIX A Baseline Characteristics Reported in Select mRCC Trials (continued)

\begin{tabular}{|c|c|c|c|c|c|c|}
\hline \multirow[b]{2}{*}{ Characteristic } & \multirow{2}{*}{$\begin{array}{c}\text { RECORD-1 }^{11} \\
\text { Everolimus } \\
(\mathbf{n}=277)\end{array}$} & \multicolumn{2}{|c|}{ CheckMate- $025^{20}$} & \multicolumn{2}{|c|}{ METEOR $^{18,19}$} & \multirow{2}{*}{$\begin{array}{l}\text { AXIS10 } \\
\begin{array}{l}\text { Axitinib } \\
(\mathrm{n}=361)\end{array}\end{array}$} \\
\hline & & $\begin{array}{l}\text { Nivolumab } \\
(\mathbf{n}=410)\end{array}$ & $\begin{array}{l}\text { Everolimus } \\
\quad(n=411)\end{array}$ & $\begin{array}{l}\text { Cabozantinib } \\
\quad(\mathbf{n}=330)\end{array}$ & $\begin{array}{l}\text { Everolimus } \\
(\mathbf{n}=328)\end{array}$ & \\
\hline Radiotherapy, \% & 31 & & & 33 & 33 & \\
\hline Nephrectomy, \% & 97 & 89 & 87 & 85 & 85 & \\
\hline \multicolumn{7}{|l|}{ Metastatic sites, $\%$} \\
\hline Lymph nodes & 76 & & & & & \\
\hline Lung & 73 & 68 & 66 & & & \\
\hline Bone & 37 & 19 & 17 & NR & NR & NR \\
\hline Liver & 33 & 24 & 21 & & & \\
\hline Other & 51 & & & & & \\
\hline Kidney & 12 & & & & & \\
\hline Brain & 6 & & & & & \\
\hline \multicolumn{7}{|l|}{ Disease sites, \% } \\
\hline 1 & 9 & 17 & 17 & & & \\
\hline 2 & 25 & & & & & \\
\hline$\geq 2$ & & 83 & 82 & NR & NR & NR \\
\hline$\geq 3$ & 66 & & & & & \\
\hline $\begin{array}{l}\text { Median time from initial diagnosis } \\
\text { to randomization, months }\end{array}$ & & 31 & 31 & & & \\
\hline \multicolumn{7}{|c|}{ Previous antiangiogenic regimens for mRCC treatment, \% } \\
\hline 1 & NR & 72 & 72 & NR & NR & NR \\
\hline 2 & & 28 & 28 & & & \\
\hline PD-L1 expression, \% & & 90 & 94 & & & \\
\hline$\geq 1$ & & 25 & 23 & & & \\
\hline$<1$ & NR & 75 & 77 & NR & NR & NR \\
\hline$\geq 5$ & & 12 & 11 & & & \\
\hline$<5$ & & 88 & 89 & & & \\
\hline
\end{tabular}


The Additional Costs per Month of Progression-Free Survival and Overall Survival: An Economic Model Comparing Everolimus with Cabozantinib, Nivolumab, and Axitinib for Second-Line Treatment of Metastatic Renal Cell Carcinoma

APPENDIX B Sensitivity of Incremental Cost per Additional Month of PFS

\begin{tabular}{|c|c|c|c|c|c|c|}
\hline \multirow[b]{2}{*}{ Parameter } & \multicolumn{2}{|c|}{ Everolimus vs. Cabozantinib, \$ } & \multicolumn{2}{|c|}{ Everolimus vs. Nivolumab, \$ } & \multicolumn{2}{|c|}{ Everolimus vs. Axitinib, \$ } \\
\hline & Low Value & High Value & Low Value & High Value & Low Value & High Value \\
\hline Base case & 21,338 & - & 64,570 & - & 35,012 & - \\
\hline $\begin{array}{l}\text { Everolimus PFS, } \\
\text { bounds of } 95 \% \text { CI }\end{array}$ & 14,752 & 33,284 & 20,261 & $\begin{array}{l}\text { Everolimus has } \\
\text { lower costs and } \\
\text { greater efficacy }\end{array}$ & 14,344 & $\begin{array}{l}\text { Everolimus has } \\
\text { lower costs and } \\
\text { greater efficacy }\end{array}$ \\
\hline $\begin{array}{l}\text { Comparator PFS, } \\
\text { bounds of } 95 \% \text { CI }\end{array}$ & 28,336 & 13,387 & $\begin{array}{l}\text { Everolimus has } \\
\text { lower costs and } \\
\text { greater efficacy }\end{array}$ & 31,408 & $\begin{array}{l}\text { Everolimus has } \\
\text { lower costs and } \\
\text { greater efficacy }\end{array}$ & 7,179 \\
\hline $\begin{array}{l}\text { Everolimus OS, } \\
\text { bounds of } 95 \% \mathrm{CI}\end{array}$ & 22,901 & 19,343 & 72,906 & 53,933 & 40,014 & 28,630 \\
\hline $\begin{array}{l}\text { Comparator OS, } \\
\text { bounds of } 95 \% \mathrm{CI}\end{array}$ & 20,400 & 23,510 & 43,841 & 64,570 & 26,395 & 42,834 \\
\hline $\begin{array}{l}\text { Everolimus WAC price, } \\
\pm 25 \%\end{array}$ & 31,019 & 11,658 & 116,200 & 12,941 & 65,990 & 4,035 \\
\hline $\begin{array}{l}\text { Comparator WAC price, } \\
\pm 25 \%\end{array}$ & 15,122 & 27,554 & 1,287 & 127,854 & $\begin{array}{l}\text { Axitinib has lower } \\
\text { costs and greater } \\
\text { efficacy }\end{array}$ & 71,203 \\
\hline AWP prices & 26,026 & - & 73,894 & - & 39,183 & - \\
\hline $\begin{array}{l}\text { Everolimus treatment } \\
\text { duration, } \pm 25 \%\end{array}$ & 31,899 & 17,818 & 120,893 & 45,796 & 68,806 & 23,748 \\
\hline $\begin{array}{l}\text { Comparator treatment } \\
\text { duration, } \pm 25 \%\end{array}$ & 5,296 & 21,338 & 44,644 & 64,570 & 1,605 & 35,012 \\
\hline $\begin{array}{l}\text { Other postprogression } \\
\text { costs, } \pm 25 \%\end{array}$ & 21,373 & 21,303 & 64,478 & 64,663 & 35,096 & 34,929 \\
\hline $\begin{array}{l}\text { Duration of third-line } \\
\text { treatment, } \pm 50 \% \text { or } \pm 25 \%\end{array}$ & 21,854 & 21,338 & 52,950 & 64,570 & 36,662 & 35,012 \\
\hline $\begin{array}{l}\text { Cost of adverse events, } \\
\pm 25 \%\end{array}$ & 21,323 & 21,354 & 65,975 & 63,166 & 33,762 & 36,262 \\
\hline
\end{tabular}

Note: All costs are in 2016 U.S dollars.

$A W P=$ average wholesale price; $C I=$ confidence interval; $O S=$ overall survival $P F S=$ progression-free survival; $W A C=$ wholesale acquisition cost . 